UDC 82-994

DOI https://doi.org/10.24919/2308-4863/39-2-15

Oleh KOLIADA,

orcid.org/0000-0003-1869-1260

Candidate of Philological Sciences,

Associate Professor at the Department of Germanic Philology and Foreign Literature

Zhytomyr Ivan Franko State University

(Zhytomyr, Ukraine) o.v.kolyada@gmail.com

Ivanna IEVITIS,

orcid.org/0000-0002-0048-8507

Candidate of Philological Sciences,

Senior Lecturer at the Department of English Philology and Translation

Zhytomyr Ivan Franko State University

(Zhytomyr, Ukraine) ivanna.dmitrieva1991@gmail.com

\title{
FATE AS A PHILOSOPHICAL AND LINGUISTIC CONCEPT OF SAMUEL BECKETT'S DRAMA OF THE ABSURD
}

The article is aimed at researching some features of existential phenomenon of fate in the context of Samuel Beckett's Drama of the Absurd. Addressing absurdity as a backdrop of human existence allows the authors to make some conclusions on present subject-matter of a modern man, in particular to consider an idea of panlogism as a source of routine and vanity whereas its rejection suggests an optional spontaneous existence of possibilities. Samuel Beckett's creativity is a vivid embodiment of the philosophy of the absurd, where concepts such as fate and fatum become central to the definition of the writer's outlook. The playwright creates plots of the play where the characters resemble puppets, dolls, or sketched machines that move in a certain direction. The late work of the writer generally abandons language as the main mechanism for the embodiment of meaning. Such techniques clearly manifest the detachment, characters are doomed and forced to perform certain actions that are not really dependent on the will and desires of the main characters. Such tendencies hinder the flow of thought towards such a concept as "fatum", which actually plays one of the most prominent functions in the playwright's work. It should be noted that the concept of fatum is a kind of coincidence, this type of concept is fundamental in the formation of the vector of thinking of the writer. In the context of linguistic analysis, it is possible to distinguish the semantic fields that characterize Samuel Beckett's "theater of the absurd", such as the semantem of judgment and the semantem of language. The irrationalist paradigm of the playwright's creativity owes to an irrationalist philosophy and a nihilistic outlook. Considering these philosophical trends, one can confidently claim the concept of fatum as fundamental in Samuel Beckett's work.

Key words: fate, absurd, panlogism, theatre of the Absurd.

олег КОЛЯДА, orcid.org/0000-0003-1869-1260 кандидат філологічних наук, дочент кафедри германської філології та зарубіжної літератури Житомирського державного університету імені Івана Франка (Житомир, Україна) o.v.kolyada@gmail.com

Iванна IEBITIC,
orсid.org/0000-0002-0048-8507
кандидат філологічних наук,
стариий викладач кафедри англійської філологї̈ та перекладу
Житомирського державного університету імені Івана Франка
(Житомир, Украйна) іvanпа.dmitrieva1991@gтаіl.com

\section{ДОЛЯ ЯК ФІЛОСОФСЬКО-МОВНА КОНЦЕПЦІЯ ДРАМИ АБСУРДУ САМУЕЛЯ БЕККЕТА}

Статтю спрямовано на дослідження деяких особливостей екзистенційного явища долі в контексті «театру абсурду» Семюеля Беккета. Розгляд абсурду як задля людського існування дає змогу авторам зробити деякі висновки з нинішньої теми сучасної людини, зокрема розглянути ідею панлогізму як джерела буденності та 
марнославства, тоді як його відкидання передбачає необов'язкове спонтанне існування можливостей. Творчість Семюеля Беккета постає яскравим утіленням філософії абсурду, де такі поняття, як «доля» та «фатум», стають основними у визначенні світогляду письменника. Філософські та світоглядні погляди письменника відчутно корелюють з ідеєю приреченості людського існування. Драматург створює сюжети п'єси, де персонажі нагадують маріонеток, ляльок або схематизованих машин, які рухаються за певно визначеним напрямом. Пізня творчість письменника взагалі відмовляється від мови як основного механізму втілення сенсу. Подібні техніки яскраво маніфестують відстороненість та приреченість персонажів, які змушені виконувати певні діі, які насправді не залежать від волі та бажань головних героїв. Учинки героїв часто вказують на їх механічність $i$ повторюваність, асоціюються з невідворотністю так званої долі чи майбутнього. Яскравим прикладом постає n'єса «Квадрат», жанрове визначення якої балансує на межі літератури та перформансу. Такі тенденції скеровують потік думки в напрямі такого поняття, як «фатум», яке насправді відіграє одну з найбільш визначних функиій у творчості драматурга. Варто відзначити, щчо поняття фатуму постає свого роду випадковістю, подібний концепт є основоположним у формуванні вектору мислення письменника. У контексті лінгвістичного аналізу можливо виділити семантичні поля, які характеризують беккетівський театр абсурду, такими постають семантема суду та семантема мови. Ірраціоналістська парадигма творчості драматурга завдячує ірраціоналістській філософії та нігілістському світогляду. 3 огляду на подібні філософські тендениії, можна з упевненістю стверджувати про кониепт фатуму як основоположний у творчості Семюеля Беккета.

Ключові слова: доля, абсурд, панлогізм, театр абсурду.

The problem statement. Modern philosophy and related educational subjects have been theoretical or solely transcendental within Kant's doctrine as the ones which can be throughly thought over but impossible to apply to everuday life. Those basic principles are distanced from routine and examplify themselves as suggestions on the ideal unlike a real person who desparately seeks feasible manifestation of philosophical ideals to form one's solid viewpoint.

Therefore, literature helps to arrange a certain philosophical niche or philosophical art - an ideal combination of irrationality, based on imagination, and rationality, logic-centred. As a result, such philosophical art facilitates integral perception of reality and develops inductive cognition that reinforces individual progress related to personal experience rather than following a dogmatice deductive model of an idealized prototype. Focusing our attention on Beckettean conceptual art we suggest to reveal fate as a phenomenal concept of philisophical art.

Recent research and publications analysis. An overlook on the recent researches on the problem of fate as a philosophical concept within a particular artistic genre, theatrical absurdism in particular, seems to be non-existent in Ukrainian studies which basically deal with translations and critical analysis of the plays, therefore novelty and necessity of the suggested subject of the research is valid contributing both to the specification of the philosophical and artistic phenomena of the concept of fate.

Presenting main material. The concept of fate definitely highlights the conceptual framework of the Drama of the Absurd both as a means of understanding one's essence and as a criterion of defining the possible ways of development of culture and mankind. One among few philosophical tendencies is closely related to the European Drama of the Absurd on the ground of priority of its agenda that is a metic- ulous insight into the relations between a world and man. This tendency is the philosophy of life-affirmation and history with modified concepts of Nietzsche, Simmel, Spengler and others.

We remember that the years of Beckett's maturity coincide with the pan-European existential boom with the acceptance of the limits of both rational way of thinking and the respective artistic reflection. For Beckett the revolt against the absolute rationalized knowledge is a Modernist co-work with James Joyce and French Resistance support with eventual self-exile, expatriation and bilingualism that proved to be fateful: "I prefer France at war to Ireland neutral" (6).

In the philosophy of life-affirmation and history, for instance in the theses by Simmel ("On Social Differentiation", "Sociology: Investigations on the Forms of Sociation", "The View of Life") and Spengler ("The Decline of the West") the concept of fate is an aim-oriented vector of life force which undergoes some modifications under certain circumstances. On one hand, for Simmel fate correlates with such a state of human existence when the external influences change the vector radically. In other words, fate hereunder is viewed as a synonym to an incident, a chance which is one of the domineering features of the Beckettian theatre.

The idea of direction (vector), on the other hand, for Spengler is not enough in order to understand the concept of fate. He states that life is chaotic and devoid of meaning, hence of the very aim and direction. Fate in his philosophy is an inner logic of the life itself, its profound regularity which depends on personal subjective processes and contrasts with natural laws or material factors. So, taking into account both, Simmelean and Spenglerean hypotheses we deal with two fundamental viewpoints: objective and subjective.

Despite obvious differences both can be treated as a unity in the context of the Drama of the Absurd. 
Both philosophers express the central Absurdist idea of a total dependence of a small man on the forces that exercise direct and unlimited influence on his life, directing him and establishing valuable orientations. The reason that our life belongs both to pure conscious or logic and is filled with emotions enables us to speculate on and deal with the sphere of existence (not simply essence). It is in the sphere of existence that such concepts as love, sadness, death gain their meaning.

Surely, we can analyse the aforementioned notions without applying the emotions, though when the latter are included and equally decide upon the essence of one's existence there appears a necessity to operate the concept of fate which transforms one's essence into existence. Such existential emotions that originate from Beckett's biography are of a great importance in his theatre. For instance his recollection after the visit to his mother who suffered from Parkinson's disease: "Her face was a mask, completely unrecognizable. Looking at her, I had a sudden realization that all the work I'd done before was on the wrong track. I guess you'd have to call it a revelation. Strong word, I know, but so it was. I simply understood that there was no sense adding to the store of information, gathering knowledge. The whole attempt at knowledge, it seemed to me, had come to nothing. It was all haywire. What I had to do was investigate not-knowing, not-perceiving, the whole world of incompleteness" (Shainberg, 5).

As stated, Beckett tensely intertwines drama and privacy, intuitively following ancient Greek experience of universalization of man via theatricality of one's being and reducing personal existence to acting in community. That aforementioned millennium-aged period of antiquity keeps memories of a person as perfect yet views those as an actor whose specific role is quite abstract, that is a role if performed according to the master plan of fate, because it is perceived not as a simple continuum of all the variety of subjective experiences, but demiurgic origin. In order to be represented and conceived an actor has to perform one's (hi)story within the margins of existential tension to break through and the audience identify themselves with the performance, swapping parts with an actor, both grasp absolute order of the spontaneous ways of life which seem to be totally irrelevant and absurd for common sense.

Therefore, fate is one of the prominent concepts that can be viewed with an accent upon determination of human life by solely external factors or, on the contrary, on the spiritual sphere. In the philosophy of life-affirmation and history fate is dependence which is perceived on both rational and emotional levels.
In the long run, it is possible to speculate on fate as a concept that reveals integral variants of being to accumulate reason, meaning and specifications of the subjective activity. Consequently it is not a surprise that most of the scholars of philosophic anthropology study the peculiarities of fate bridging the gap between individual and collective.

Regardless, such scholars state that fate is absolutely unknown and terrific yet potential as far as human being concerns and thus possible to be transformed into foreseeable and manageable. Paradoxically many famous thinkers in fact point attention on inadequacy of fear towards unknown and represent as illogical and absurd the attempts to forecast future events as favourable to a person drowned in vanity. Contextually, theatre of the Absurd works existential therapy for those who, paraphrasing Beckett, have not yet dissolve in consumerism of ideological games and intellectual slavery.

The dramatic disappearance of the language in one of the most unique Beckett's plays "Quad" accentuates attention on the concept of fate. The play is absolutely non-verbal and is an alternative to the language embodiment of the plot. Characters in "Quad" do not say a word, the whole action focuses on movements and walking within a conditional square, reminiscent of the puppet movement on a certain axis from which they will never descend. In the play the action is constructed using completely different means than verbal ones and this prominent lack of language makes room for image and sound. In other words, "Quad" manifests the end of the struggle between language and the imagery from which imagery emerges victorious. In the play itself there are four characters, their age and gender are not specified by the author. The characters are different, we can see that by the color of the mantle they wear. The first character is white, respectively, the next three are yellow, blue and red. In addition, each of them has a specific musical background that sounds as they move on stage. Each of the characters periodically enters the square, moving along a certain trajectory, leaving it in the same way, then reappearing and continuing. Players move mechanically, playing the prescribed path and stepping in a harmonious, well-honed rhythm without interfering with each other. The only obstacle in their path is the center of the square, which they never go through, and they always take the decisive step away, as if afraid of encountering another player in the center or fearing the center itself. However, bypassing the center does not cause a violation of a well-defined rhythm, it looks harmonious enough that the characters do not think about it, but do it mechanically, under the supervision of a puppeteer. Characters are doomed to move in a specific direction, always avoiding the center. 
The trajectory of the character movement is clear: the first player appears at point $\mathrm{A}$, completes his direction, and then the third player joins him. After completing the route, they are joined by a fourth character. Together, the three complete their itineraries until the second character arrives on stage. The four of them follow their own defined trajectory until the first and second leave the stage, at which time the third and fourth continue and complete their routes. The third character is then released, and the second and fourth players continue to move until the the fourth leaves the square. By fixing the end of the first episode, the second player continues, opening 2 episodes, completes his direction and joins the first one. "Etc. Umbroken movement" (Beckett, 1: 451).

Beckett's concentration on clarity and monotony puts him at risk of literary criticism, his characters are considered as puppet characters. The concept of "Quad" is completely devoid of language. The play's characters perform a definite, choreographic scheme, acting as if they were inside a computer program, a machine that created a certain path for their bodies. The "Quad" begins a new round of development for Beckett's creativity, where the disappearance of language has become a mechanized model, reminiscent of the traditional concept of drama, where the main is not just an action but a conflict. If there has been conflict in the playwright's previous plays, then this work is completely devoid of conflict. The "Quad" turns into an endless, monotonous ritual along a defined trajectory, where the indentation is equivalent to collapse. All that remains to be considered in the play is fate. As we can see, the playwright depersonalizes the actors to clear mathematical units that serve as a means of translating the model of motion, in other words: characters do not function as individual subjects with human characteristics, but are transformed into objective components that are combined with other elements for the desired aesthetic effect. S. Beckett calls the "Quad" a play consisting of four players, light and sound. The playwright reaches the goal of reducing the language to zero, portraying characters like robots or dolls.

From this point of view, it should be noted that the Irish playwright tried to find new ways of transmitting values and to avoid the usual use of language. Thus he was searching for a semiotic field other than the linguistic one. It is mathematics that offers those signs that are already ready for use, which are logical and multifunctional. By their definition, this process began from the moment when the playwright switched from prose to theatre.

Beckett's authenticity is associated with a complete reduction, as if the playwright completely "forgets" the traditional vision of the play, in other words destroys the classic vision of the work, which contains a plot, an action, a conflict where the characters conduct heated dialogues. giving space to deploy verbal duels. Instead, the creativity of the author turns into a place where the usual elements dissolve, and their place is occupied by others: music, play, pantomime, static, choreography, mathematical aesthetics and more. Such expressive experimentation did not fit within the boundaries of classical theater, forcing drama theorists to consider Beckett's work as an interdisciplinary phenomenon at the intersection of other arts. So far, theatrical practice has referred to action and dialogue, where the viewer can appreciate what is happening on stage through the dialogues of the characters.

In "Cascando" and "Words and Music" the melody is not just part of the play, it becomes a full-fledged character. In "Words and Music", the writer actually personifies music. One of the main characters, Croak has a conversation with two friends (or those he wants to see as friends), one of them is Words and the other is Music. By the way, they also have names, in the drama "words" are called Joe, and "music" is Bob. Let's analyze one of the dialogues: "Croak: Joe. Words: (modestly) Yes, my Lord. Croak: Bob. Music: Quiet, muffled... Croak: Bob! Music: As before. Croak: Love!" (Beckett, 1: 288).

As we can see, music not only plays the role of devoid of emotion of the characters, it has its own character and emotionally expressive image, different from the quiet, muted melody to the loud sound, then muffling to reaching the high tones. Beckett separately distinguishes Music and Words as full-fledged characters, giving them cues in the canvas of the work, thus turning the music into an actor. The words are also sung in response to Croak's monologue. In addition, not only Croak is in conversation with the Music, but also the Words themselves, as one of the characters turn to it, thus forming a dialogue. Even considering one of the early plays one can notice the influence of the playwright's musical thinking.

Peculiar analytical style of the playwright leads to minimalism and clarity bordering on the exact sciences. In addition, partially replacing the language with music and painting, Beckett also resorts to choreography, pantomime. Exhausting techniques that are characteristic of other arts, the writer comes to the so-called "nothing". In other words, the function of meaning is played by pauses, silences, incomprehensible whispers or mutterings, which also amplify the effect of musicality.

As we can see, the playwright's unique style reflects his peculiar personality, which makes Beckett's work more distinctive. This tendency is manifested by the involvement of the seemingly traditional play struc- 
ture of heterogeneous elements, the creation of often unexpected combinations, the construction of mathematical graphs and tables, which has led to increasingly prominent reduction techniques. As a result, the playwright feared or, on the contrary, jokingly said that such a reduction, a large number of artistic inclusions and pauses could cause him to ever simply write a white piece of paper.

If we project the concept of fate into the sphere of linguistics we can differentiate several semantic fields there. The first invariant is a semanteme of trial connected with such meanings as good and bad luck related to the myths about gods who cast a lot. In the Drama of the Absurd we trace such dependence in the opposition "small man :: Das Man" related to the myth of the Last Judgment when a man is being condemned ("Theatre II" by Beckett, "Victims of Duty" by Ionesco, "Strip-tease" by Mrożek). During such a trial the irrational essence of fate is taken into account which is viewed as incomprehensible incident and this is truly coherent with the poetics of the Absurdist.

The second invariant is a semanteme of language connected with such meaning as doom, Latinate fatum which is unavoidable, compulsory, and dependent. When we view fate in the context of a language, speech, or declamation we appeal to fatum, irrational force that transforms a word into an element. Hence we have a new modus of the invariant, related to the myth of Babylon Tower ("Play" by Beckett, "Landscape" by Pinter, and "The Bald Soprano" by Ionesco). Dealing with fatum, we presuppose that it is not a human voice but the voice of gods that a man is predestined to listen to and correlate his actions with ("Act without Words I" and "Act without Words II" by Beckett). An Absurdist fate has a direct link to the mythological one which deprives man of his own voice and makes him listen to the prophetic one ("Waiting for Godot" by Beckett) 1 .

So, when viewing the concept of fate through the invariants of trial and language (fatum) in the philosophy of life-affirmation and history we logically tend to direct the Absurdist vector into the irrational world outlook. Irrationalists are the first philosophers who criticize the classical tradition about reality as a strictly determined system with a steadfast centre (god, law, reason). On the contrary, the world is viewed by Schopenhauer, Hartmann, Nietzsche, Freud, Dilthey, Bergsson as a chaotic stream with a negligible segment of the conscious, which is but technical: "The confusion is not my invention ... It is all around us and our only chance is to let it in.

\footnotetext{
1 "Hoc nisi fata darent, nunquam fortuna tulisset" (If it weren't for the fate, that wouldn't have happened").
}

The only chance of renovation is to open our eyes and see the mess ... There will be a new form, and ... this form will be of such a type that it admits the chaos and does not try to say that it is really something else" (Shainberg, 6). Consequently the position of a small man in such a world is but modest. In Schopenhauer's "The World as Will and Representation" the world is presented through dreams and the role of a human reason is to catch those illusionary acts of will. This is what any protagonist (small man) does in the Drama of the Absurd: reduced to a mythical existence man is unable to tell good from wrong, catching as an instrument some vibrations of the world will, world fate and power. In the "Philosophy of the Unconscious" Hartmann deals with the outside world as a collective trial, which is realized in the Absurdist reality about the world as the non-existence led by the blind will producing suffering and death.

Nietzschean nihilistic postulates as a consequence of the cultural crisis at the turn of the centuries are more than welcome into the Drama of the Absurd. In his works a small man is a slave lost in the world without meaning dreaming about Übermensch. Such motives are true in the Absurdist theatre when a small man constantly tries to impose his small power and will upon the heighbour, when in fact both are subjugated ("Endgame" by Beckett, "Fando et Lis" by Arrabal). The idea behind nihilism in the Absurdist theatre is reduced to the concept of the exhaustiveness of the intellect possibilities and gradual recurrence to the instincts and such Nietzschean eternal recurrence is related to the mythologeme of circle, the myth of Sisyphus, and mythopoeic motive of eternal return.

"The life of every individual, if we survey it as a whole and in general, and only lay stress upon its most significant features, is really always a tragedy, but gone through in detail, it has the character of a comedy. For the deeds and vexations of the day, the restless irritation of the moment, the desires and fears of the week, the mishaps of every hour, are all through chance, which is ever bent upon some jest, scenes of a comedy. But the never-satisfied wishes, the frustrated efforts, the hopes unmercifully crushed by fate, the unfortunate errors of the whole life, with increasing suffering and death at the end, are always a tragedy. Thus, as if fate would add derision to the misery of existence, our life must contain all the woes of tragedy, and yet we cannot even assert the dignity of tragic characters, but in the broad detail of life must inevitably be the foolish characters of a comedy"2.

\footnotetext{
${ }^{2}$ Review 'Waiting for death. The philosophical significance of Beckett's 'En attendant Godot" by Ramona Cormier and Janis L
} 
Conclusions. Essentially rooted in human fate and human destiny Beckett demonstrates a deep landscape, or wasteland, of the human being. Principally absurd existence of a person is aimed at modifying to bring in any meaning, hence adherence to panlogism prevents them to plunge into stream of life since the most choose a position of a viewer upon own or someone's being. As a result, a scope of emotions an individual is open to is limited to sympathy, or empathy, when those sympathize the fate of an actor and themselves.

Modernist and especially post-modernist art is exceptionally powerful to break the conventions and make people extract themselves from cliché of the monochromatic world to perceive colours of absurdity which are above good and bad, right or wrong. As a result, absurd regenerates aboriginal idiosyncratic identity, liberates creative origins and spontaneity above routine and vanity because absurdity nullifies any sense or argument, therefore the latter is even theoretically impossible.

Under such condition the only thing that remains is action, an act to be implemented into a never-ending myriad of existence as non-fixed and ever changing to revive the world within absurd since its cells pulsate through actions (or at least intentions). Ultimately, absurd allows to reveal a potential value where logic is destined to view routine and, on the contrary, mythbreaks the value of artificiality based on mass opinion of 'small men' directing an impulse to get astound realizing that "Nothing is more real than nothing".

\section{BIBLIOGRAPHY}

1. Beckett S. The Complete Dramatic Works, Faber \& Faber, 2006. P. 41.

2. Beckett S. Three Novels: Molloy, Malone Dies, The Unnamable. - Grove/Atlantic, Inc., 2009. - C. 186.

3. Beckett S. Waiting for Godot. London, Faber \& Faber, 1959. P. 41.

4. Cormier Ramona J.L. Review. Waiting for death. The philosophical significance of Beckett's "En attendant Godot". URL: http://www.english.fsu.edu/jobs/num07/Num7Hesla.htm

5. Shainberg L. Exorcising Beckett. I prefer France at war to .Ireland neutral. The Paris Review 104. Fall 1987. URL: http://www.theparisreview.com.

\section{REFERENCES}

1. Beckett S. The Complete Dramatic Works, Faber \& Faber, 2006. P. 41.

2. Beckett S. Three Novels: Molloy, Malone Dies, The Unnamable. - Grove/Atlantic, Inc., 2009. - C. 186.

3. Beckett S. Waiting for Godot. London, Faber \& Faber, 1959. P. 41.

4. Cormier Ramona, J.L. Review. Waiting for death. The philosophical significance of Beckett's "En attendant Godot". URL: http://www.english.fsu.edu/jobs/num07/Num7Hesla.htm.

5. Shainberg L. Exorcising Beckett. I prefer France at war to Ireland neutral. The Paris Review 104. Fall 1987. URL: http://www.theparisreview.com. 